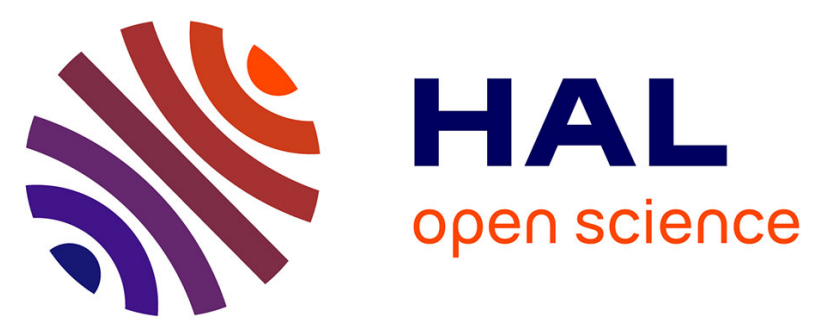

\title{
Hotspot or blind spot? Historical perspectives on surveillance and response to epidemics in the Central African Republic
}

\author{
Pierre-Marie David, Emmanuel Nakouné, Tamara Giles-Vernick
}

\section{To cite this version:}

Pierre-Marie David, Emmanuel Nakouné, Tamara Giles-Vernick. Hotspot or blind spot? Historical perspectives on surveillance and response to epidemics in the Central African Republic. International Journal of Public Health, 2020, 65 (3), pp.241-248. 10.1007/s00038-020-01338-x . pasteur-03264078

\section{HAL Id: pasteur-03264078}

https: / hal-pasteur.archives-ouvertes.fr/pasteur-03264078

Submitted on 17 Jun 2021

HAL is a multi-disciplinary open access archive for the deposit and dissemination of scientific research documents, whether they are published or not. The documents may come from teaching and research institutions in France or abroad, or from public or private research centers.
L'archive ouverte pluridisciplinaire HAL, est destinée au dépôt et à la diffusion de documents scientifiques de niveau recherche, publiés ou non, émanant des établissements d'enseignement et de recherche français ou étrangers, des laboratoires publics ou privés. 


\title{
Hotspot or blind spot? Historical perspectives on surveillance and response to epidemics in the Central African Republic
}

\author{
Pierre-Marie David ${ }^{1} \cdot$ Emmanuel Nakouné $^{2} \cdot$ Tamara Giles-Vernick $^{3}$
}

Received: 3 July 2019/Revised: 3 February 2020 / Accepted: 5 February 2020 / Published online: 12 February 2020

(c) Swiss School of Public Health (SSPH+) 2020

\begin{abstract}
Objectives The Central African Republic (CAR), a site of recurrent disease emergence, developed a noteworthy epidemiological surveillance system from the colonial period, but its health measures have remained among the world's lowest. To understand this disparity between surveillance and public health, we examined selected moments in its history of surveillance and changing relations with public health structures.

Methods We conducted archival research in CAR and French archives and 18 semi-structured interviews with key researchers working in CAR.

Results We find long-term continuities in privileging surveillance over the health system and population health, making the CAR a "hotspot" for emerging diseases and a "blind spot" of primary health care. From the colonial period, the country attracted considerable support for surveillance, without concomitant investment in public health system. Political disputes and financial constraints have obscured real primary care needs on the ground.

Conclusions As both a hotspot and a blind spot for global health, the CAR signals the need to reorient health interventions to address the long-term health of Central African people.
\end{abstract}

Keywords Surveillance $\cdot$ Disease emergence $\cdot$ Epidemics $\cdot$ Central Africa $\cdot$ History $\cdot$ Pasteur

\section{Introduction}

Central Africa has long been a region of disease emergence and epidemics, from sleeping sickness and HIV to Ebola and Marburg viruses. Multiple histories have assessed its experiences with epidemic outbreak and response (Headrick 1994; Lyons 2002; Pepin 2011). We know little, however, about the region's history of epidemiological

Pierre-Marie David

pierre-marie.david@umontreal.ca

Emmanuel Nakouné

emmanuel.nakoune@pasteur-bangui.org

Tamara Giles-Vernick

tamara.giles-vernick@pasteur.fr

1 Faculty of Pharmacy, Université de Montréal, Montréal, Canada

2 Institut Pasteur de Bangui, Bangui, République Centrafricaine

3 Anthropology and Ecology of Disease Emergence, Institut Pasteur, Paris, France surveillance, nor about how surveillance structures engaged, overlapped, or conflicted with formal health structures.

The Central African Republic (CAR) has particular significance in this history of disease emergence, surveillance, and health systems. Its rich disease ecologies have produced multiple disease emergences in the past century, from sleeping sickness to monkey pox (Jamot 1920; Kalthan et al. 2018). Its potential for disease emergence rests on the presence of known and potential pathogens, on broader social, ecological, political conditions, and on porous frontiers with Cameroon, Democratic Republic of Congo, Republic of Congo, South Sudan, and Sudan (Pepin 2011; Kalthan et al. 2018). Responsibility for detecting these threats during the colonial period was in the hands of colonial health authorities, who developed for certain pathogens like sleeping sickness a noteworthy surveillance system. Surveillance now rests with the Institut PasteurBangui (IPB), in collaboration with CAR provincial health structures. 
Yet despite a well-developed surveillance system, this "at-risk" country has some of the world's lowest health rankings, including those for life expectancy at birth, infant mortality, proportion of chronically malnourished children (UNDP 2019). This dire health situation constitutes a "blind spot" linked to multiple historical, political, and economical factors, resulting in the country's inability to attract sufficient investment from global health actors, institutions, and organizations. In this paper, we argue that the CAR and the colonial territory that it comprised before independence have long been paradoxical one: it is both a "hotspot" for emerging diseases and a "blind spot" of primary health care (Brown and Kelly 2014). How has a comparably robust surveillance system come to exist alongside weak health structures and poor population health measures? A historical analysis of surveillance can offer crucial insight into this question. Here we examine how institutions and actors detected and tracked pathogenic emergence and re-emergence and how emerging disease surveillance affected primary care and health infrastructures. We explore the historical implications of these past priorities and investments for contemporary configurations, structures, and differential investments in tracking disease emergence and managing health of Central African people. Our historical analyses, although partial, can help shed light on the CAR's present surveillance and healthcare capacities.

To investigate historical relations between surveillance and primary health care, we trace selected moments in the CAR's history of epidemiological surveillance and its relations with public health structures. Our selected cases were determined by existing archival documents in France and the CAR and supplemented by semi-structured interviews of Central African biomedical actors. Following an overview of the early twentieth-century colonial health system, we address two colonial examples of surveillance and health care (sleeping sickness and influenza). We then assess IPB's early postcolonial history and its developing surveillance capacity for hemorrhagic fevers and other zoonotic diseases in collaboration with French research institutions. We extend our analysis in a discussion addressing contemporary surveillance, CAR's healthcare system, and the broader dynamics of global health-a late twentieth-century transformation of international public health, characterized by prominent global coordinating institutions (WHO, World Bank), massive investments from philanthropic foundations, public-private partnerships, and an orientation toward technical solutions (Packard 2016).

\section{Methods}

\section{Defining surveillance}

Although epidemiological surveillance in the CAR has a long history, defining "surveillance" before the midtwentieth century remains a challenge. Most specialists credit Alexander Langmuir with codifying modern surveillance in the early 1960s (Fearnley 2010). Nevertheless, certain surveillance tools existed before then, including contact tracing and infection control measures (isolation, quarantine, and mobility restrictions) (GilesVernick et al. 2011). We understand "surveillance" as a practice that changes over time and in relation with public primary care; it includes multiple medical and administrative data collection practices and control measures permitting epidemics' identification, tracking, and response.

\section{Setting}

We explore various examples of surveillance interventions in the territory corresponding to the CAR, which has a lengthy history of French support for, but also substantial underinvestment and understaffing in its formal health system. In the early twentieth century, the CAR was the French colony Ubangi-Shari, part of French Congo from 1903 and subsequently integrated into French Equatorial Africa (AEF) in 1910. From its beginning, Ubangi-Shari's health system lacked personnel, health structures, and financial resources, a condition that continued well into the 1930s (Headrick 1994). Young doctors were generally poorly prepared for realities on the ground; insufficiently trained African nurses provided most care (Headrick 1994). Beyond Bangui, only five Indigenous Medical Assistance personnel (AMI) staffed primary care posts until 1930, and rare Christian missions complemented this rudimentary system (Conan 1913: 27; Headrick 1994). In the 1950s, expanding French investment was channeled into hospital construction and the posting of medical doctors in each province. This assistance continued following CAR's independence, sustaining the country's new national health system in the 1960s. By the early 1980s, France contributed some 64 medical personnel to CAR, including 35 doctors and technical advisors to the Ministry of Health.

\section{Fragmented archives and data collection}

Historical investigation of colonial and postcolonial CAR remains a major challenge because of scarce documentary evidence. To evaluate structures and practices of surveillance and health care, we consulted archives at the Diplomatic Archives of Nantes, the French Embassy fund 
(1960-1995), and the Bangui Governor's Fund (1907-1960). We also consulted Institut Pasteur archives (Paris); the Centre des Archives d'outre-mer (Aix-enProvence, France); the Historical Defense Service Fund (Toulon and Vincennes). Finally, we conducted 18 openended interviews with current and former Institut PasteurBangui (IPB) researchers and directors, who contributed to identifying emerging diseases, consulted for international agencies, and reflected on their experiences at this research institute.

Our case selection reflects the slim historical record, resulting from lost documents and perhaps haphazard recordkeeping. Colonial archival documents offered little insight into other health cultures and practices in UbangiShari and could not support a linear history of surveillance. Instead, cases presented here provide selective insights into past moments, allowing us to trace continuities and shortcomings around relations between epidemiological surveillance and medical care and public health.

\section{Results}

\section{Ubangui-Shari's surveillance of sleeping sickness, 1917-1919}

Eugène Jamot was a French physician, celebrated by some as a hero of French colonial medicine (Moulin 1992) and known for his campaigns against sleeping sickness in Central and West Africa. An early assignment brought him to Ubangi-Shari between 1917 and 1919, where he initiated large-scale surveillance and control of sleeping sickness. This scheme was a crucial pilot, both in the colony's history and in French efforts to control sleeping sickness throughout AEF. Sleeping sickness remained a critical health concern in Central Africa from 1900 to 1940, and diverse colonial powers struggled to address recurrent epidemics using multiple biomedical and ecological strategies (Headrick 1994; Worboys 1994). France's efforts, founded on Jamot's approach, were developed first in Ubangi-Shari during his leadership of the now-defunct Institut Pasteur of Brazzaville (Congo) and subsequently expanded in Cameroon from 1922. Although the Cameroonian initiative attracted much historical attention (Sonné 1994; Bado 2011), to our knowledge, his early efforts to develop Ubangi-Shari's surveillance strategy (Jamot 1920) have been little investigated.

Jamot developed a monitoring system based on mobile teams and experimented with control measures, including segregation of the sick from the healthy and the coercive use of atoxyl, an attenuated arsenic-based treatment with serious secondary effects (Steverding 2010). This initiative ballooned from a single experimental site into an epidemiological surveillance system in just 2 years. In late December 1916, the Colonial Hygiene Council established a "temporary medical sector for the prophylaxis of sleeping sickness in Oubangui-Chari," a pilot project extending across the colony's central region (Cabinet du Gouverneur Oubangui-Chari 1917). A 30,000-square kilometer zone, roughly the size of Belgium, was covered by a team consisting of a Chief Medical Officer (Jamot), two European troops doubling as nurses, and eight African nurses. European doctors and nurses were based in the Fort Sibut operations center, with African nurses seconded to pilot towns of Grimari, Mbrès, Bouca, Dekoa, Possel, and Marali (Cabinet du Gouverneur Oubangui-Chari 1917).

The health staff received meager resources to perform their activities: three microscopes, two syringes, and 30 kilos of atoxyl. Each African nurse had two porters; two European nurses each relied on five porters and a horse, whereas the chief physician was accompanied by 12 carriers, one horse, and one automobile (Cabinet du Gouverneur Oubangui-Chari 1917). Such scanty investments were nonetheless generous in Ubangi-Shari's under-resourced context and sometimes created tensions with other medical staff. The Indigenous Medical Aid (AMI) physician earned half as much as Jamot's prophylaxis service physician (Lamblin 1919). The differential pay revealed tensions between regular health care and surveillance.

By 1919, this rapidly expanding surveillance program reached nearly 100,000 African subjects who were "examined and manipulated one by one" (Jamot 1920). What began as a modest pilot inserted itself as an alternative colonial authority with the power to capture colonial subjects and grant their freedom after disease surveillance and potential atoxyl injection. Jamot was clearly aware of the authority he and his team wielded: just 8 months after taking his position, he sent an inflammatory report to the President of the Congress of Colonial Agriculture, provocatively questioning Ubangi-Shari's administrative hierarchy (Lamblin 1918). His report provoked an outburst from the colony's Lieutenant Governor to his superior, the AEF General Governor Angoulvan (Lamblin 1918). Jamot's pilot project set the foundations for the 1920 s expansion of sleeping sickness surveillance and treatment through the Service spécial de lutte contre la maladie, funded by the Ministry of the Colonies. And these political tensions continued throughout the 1920s and 1930s, pitting Jamot and other sleeping sickness authorities against colonial administrators (Dozon 1985).

Two points emerge from this description. First, Jamot's pilot attracted investment in surveillance and treatment for a single pathogen, to the detriment of broader primary healthcare services. Rita Headrick (1994) argued that the AEF devoted resources to tracking and controlling sleeping sickness, but sorely neglected primary health. The French 
colonial administration, dependent on local resource extraction to fund its activities, ranked Ubangi-Shari as a low priority for any investment. This imbalance illustrates a salient continuity in this region: significant investment in vertically structured epidemiological surveillance alongside inadequate resources devoted to basic health care.

Second, this example reveals the political tensions that can result from well-resourced, vertical surveillance programs and political administrations. Although they manifest themselves differently in diverse settings, tensions between well-resourced surveillance and treatment operations and political authorities may ring familiar to contemporary readers. The current DRC Ebola epidemic illustrates that outbreaks, transmission, and surveillance and control efforts are never politically neutral: they occur within political contexts, and they challenge and reshape the exercise of political power (Kalenga et al. 2019).

\section{Influenza and surveillance, Bangui 1918}

The 1918 influenza pandemic constitutes a second documented event in Ubangi-Shari's history of surveillance and response. Archives documenting the epidemic are limited, but nonetheless illustrate important features of a nascent surveillance system in a context of highly limited healthcare resources.

Influenza first appeared in Bangui on November 23, 1918, two months after other African regions (Deitte 1918a). The late arrival of the epidemic reflects UbangiShari's relative isolation from the busiest transport networks. The first cases arrived with the "Linarense" steamboat traveling from Brazzaville to Bangui along the Ubangi River, a major waterway and tributary of the Congo River. Among the steamboat's occupants were its ailing captain, European passenger, and several crew, who subsequently transmitted the virus to city inhabitants (Deitte 1918a). In just over 2 weeks, Deitte, administrator in the Bangui Governor's cabinet, reported some 24 cases of flu among Europeans and 342 cases among Africans in Bangui, although flu incidence among Africans was likely underestimated (Deitte 1918d).

The initial confrontation with influenza was hampered by confusion and delays, even though the epidemic was already known worldwide. On November 29, 6 days after the arrival of the Linarense, the administrator Deitte transmitted the AEF Governor General's message that Kinshasa and Brazzaville suffered from many influenza cases. Although the head of the health service (Dr. Ricau) and one of the colony's few doctors (Dr. Huot) indicated after examining sick passengers disembarking from Linarense that they "did not think that these symptoms had anything in common with the flu," they isolated sick passengers as a precautionary measure (Deitte 1918a). On what basis they determined that the mysterious illness on the steamer was not influenza is unknown, but one crewmember had already perished. Five days later (3 December), Dr. Ricau reversed his initial assessment, officially recognizing these cases as "a serious form of lung flu" (Ricau 1918). Communication delays explain the confusion: the Linarense arrived in Bangui before news of Brazzaville's epidemic reached the Bangui officials (Deitte 1918c). Meanwhile, the city braced for another steamer arriving from Brazzaville, insisting that all precautions had been taken (Ricau 1918).

Numerous historical analyses of the 1918 influenza pandemic showed that preventive control measures and treatments were largely useless in the face of a highly virulent pathogen coupled with high human mobility, inadequate diets, and forced labor (Musambachime 1993; Craddock et al. 2010). Archival documents say little about Central Africans suffering from influenza or the epidemic's expansion beyond Bangui, but it did spread. Historical sources indicate that protecting Bangui and other towns with European populations was the priority (Deitte 1918c). In Bangui, separate "European" and "indigene" hospitals isolated those who fell ill along racial lines. Deitte issued orders to all Ubangi-Shari circumscriptions to isolate sick people, sequester afflicted villages, and in Bouca and Berberati, to deny African subjects passes to travel to Bangui, including labor recruits or traders; only "essential" subjects-those accompanying Europeans-would receive passes. Food merchants could sell their foodstuffs at the barriers of Bangui, but not enter the city (Deitte 1918b). Yet these were paper orders, and we have no evidence whether or to what extent they were implemented. Given Ubangi-Shari's dearth of infrastructure and resources, it remained patently unrealistic for the lieutenant governor to expect a district head supported by African troops and few haphazardly trained medical personnel to identify and to isolate entire afflicted villages.

These early surveillance and response measures echo important continuities between past epidemic control in colonial Africa and contemporary challenges that underfunded surveillance and health systems face in detection and response. The political pressure to "do something," even ineffectual, in the face of uncontrolled transmission is considerable. In Ubangi-Shari as elsewhere, calls for mobility restrictions, isolation, and sequestration gave the appearance of "doing something," even if such efforts were likely ineffective, particularly in a context in which the colonial administration had invested precious few resources into developing a health system.

In a contemporary context, although International Health Regulations (2005) govern regional surveillance and response to epidemic emergencies, some countries have been tempted to implement border closures despite 
criticisms that they are mostly ineffective (Bell 2003). Such strategies nevertheless continue to serve as political performance. During the 2014-2016 West African Ebola epidemic, one government response was to "fumigat[e]... all public buildings"; another was to curtail all wild meat hunting and marketing, which did not stop Ebola transmission and had negative political and economic consequences for local populations (Bonwit et al. 2018).

\section{Institut Pasteur de Bangui (IPB): between surveillance and public health}

Inaugurated in 1961, IPB is part of the Institut Pasteur International Network, a network of research institutes founded during colonial and postcolonial periods (Moulin 1992). It bears some resemblance to overseas colonial research institutions producing scientific knowledge and conducting surveillance and medical research on African subjects on the territories depending on colonial powers (Tilley 2011; Graboyes 2018). More precisely, IPB has contributed to the postcolonial reconfiguration of science, developing collaborations and producing knowledge (notably of hemorrhagic fevers and HIV) that would transform international health to global health.

IPB first achieved recognition in the 1970s through yellow fever and other arbovirus surveillance, in collaboration with French research institutions, including the $O f$ fice de la recherche scientifique et technique outre-mer (ORSTOM) (Gonzalez et al. 1979). During this decade, researchers captured more than 400,000 mosquitoes, isolated 919 viruses, and identified and described two new viruses, Bozo Arb 7343 and Arb 11266 (Saluzzo et al. 2017). In addition, IPB researcher Max Germain, an entomologist in Bangui from 1971 to 1978 , defined the concept of "emergence" and created a surveillance station in an "emergence zone" between the forest and wooded savanna in Bozo, a CAR village for which one newly identified virus was named (Germain et al. 1976).

Between the late 1970s and 1980s, the IPB-ORSTOM collaboration used IPB infrastructure developed for arbovirus research to undertake hemorrhagic fever (HF) surveillance. Germain and Pierre Sureau, former director of IPB (1972-1975), contributed their expertise to the 1976 Yambuku Ebola epidemic (in former Zaire, now DRC), near the CAR border. The arrival of virologist Jean-Paul Gonzalez and director Alain Georges (IPB director, 1979-1991) strengthened local research capacities, as did regular visits by US Centers for Disease Control (CDC) specialists.

IPB laboratories, however, remained poorly equipped for virology research, much of which was conducted at great risk, "without glove and without mask" (Anonymous1 2015). Laboratory contaminations were frequent. In response, Director Georges built a P3 laboratory equipped for HF, the only one of its kind in Africa for several years. Enhanced research capacity and facilities for HF opened up opportunities for researchers working in CAR to expand virus identification and surveillance through collaborations with the CDC and USAMRIID.

These newly expanded global collaborations were transformative for CAR surveillance capacities and paralleled broader transformations of international health to global health. Now partnering with a broader, global range of collaborators, HF researchers undertook seroprevalence studies, identifying a new HF virus, Mobala, and finding that significant proportions of CAR's population had developed antibodies against certain HF (Meunier et al. 1987; Gonzalez et al. 1984).

This strengthened surveillance capacity also made unexpected contributions, enabling the early recognition of HIV emergence in CAR. CAR's first AIDS cases were clinically identified in 1984 by clinician Dr. Jean-Louis Lesbordes (a French physician practicing in Bangui's Universitary Hospital from, 1981 to 1987) and subsequently confirmed by IPB and IP-Paris (Lesbordes et al. 1985). In October 1985, the WHO and IPB organized in Bangui the first international workshop on AIDS in Africa (Mann 1986).

The workshop provoked two salient developments. It catalyzed political tensions with Central African authorities, who feared the country would be stigmatized. Although subsequently resolved through close interactions between IPB's Director and the CAR President, this is one example of recurrent political tensions generated by HIV/ AIDS surveillance in the 1980s (Anonymous2 2015). The workshop also adopted a widely used clinical definition of AIDS and initiated an HIV/AIDS surveillance network, trying to combine surveillance and care.

CAR surveillance in the 1970s and 1980s expanded considerably, situating IPB as a globally recognized surveillance structure for disease emergence, an expansion that paralleled the emergence of global health and contributed new knowledge on HF and HIV. In the late 1980s, the CAR experienced its first Structural Adjustment plans, which massively reduced expenditures and personnel in health and social services. The country was plunged into political upheaval, economic decline, and deteriorating health indicators: maternal mortality, for instance, increased from $683 / 100,000$ in 1988 to $948 / 100,000$ in 1994 and reached 1355/100,000 in 2003 (RGPH 2003). Whereas epidemiological surveillance and knowledge expanded during this period, the CAR's health system hemorrhaged resources and personnel when, facing AIDS epidemic, it needed them most. 


\section{Discussion}

\section{Hotspots and blind spots}

Here we find long-term continuities in privileging surveillance over the health systems and population health. From the colonial period, this "hotspot" attracted considerable support for surveillance, without concomitant investment in public health. As Jamot's experiment indicates, colonial Ubangi-Shari offered a proving ground for pathogenic detection and surveillance, but political disputes and financial constraints obscured real primary care needs on the ground. Long-term support for health infrastructures, personnel, and capacities have remained a "blind spot," the consequence of specific historical conditions in which primary healthcare system remained a lesser priority.

Today, this blind spot can also be understood as a consequence of global health priorities. Other blind spots of global health, including market-driven policies, have been underscored (Keshavjee 2014). Our case study, however, signals another invisible domain. Global health pivots around two distinct but complementary preoccupations, humanitarian health and biosecurity (Lakoff 2010). Indeed, the last decade has witnessed an influx of humanitarian NGOs, which provide health services to CAR's population that public structures cannot. Simultaneously, international institutions such as the World Bank have expanded investments to bolster "preparedness" (surveillance capacities) for future epidemics. Neither humanitarian nor biosecurity priorities address CAR's public health system capacity. Although sporadic investments are made, health infrastructures and capacities remain a "blind spot."

\section{Current epidemic surveillance and response}

As a critical institution in a disease emergence hotspot, IPB continues to track emerging diseases and produce scientific knowledge about them thanks to provincial public health alerts. Although the CAR has not suffered the number or scale of outbreaks that neighboring DRC has (MuyembeTamfum et al. 2012), the country is nevertheless at risk. Still plagued by political and military insecurity, the CAR has remained largely unable to strengthen its formal health system. Since 2013, it has experienced annual monkey pox eruptions, with several outbreaks just in the last 2 years.

In 2018 alone, monkey pox epidemics occurred in Bangadou, Bangassou, and Bambari. In response, IPB conducted epidemiological surveys to estimate prevalence and developed surveys to identify the viral reservoir and assess exposure and incidence in human populations where these outbreaks have occurred. Although these surveillance practices echo 1980s HF investigations, the fundamental problems that apparently contribute to larger, more frequent monkey pox epidemics remain unresolved. High human mobility, a result of long-term armed conflict and cross-border trade between CAR and DRC, seems to have facilitated these recent emergences, which were exacerbated by poorly trained health personnel and insufficient medical resources and infrastructures (Kalthan et al. 2018).

Moreover, monkey pox is not CAR's sole recurring outbreak; yellow fever and meningitis have also reemerged in recent years (Rachas et al. 2014; Coldiron et al. 2018). These epidemic outbreaks are most often detected by medical staff in provincial health centers and confirmed by IPB in collaboration with the Ministry of Health. Despite the difficulties faced by local healthcare structures, CAR's health system remains a crucial element in the country's surveillance and epidemic control system.

What will happen if CAR suffers a major epidemic? Effective response would entail providing healthcare to a stressed general population, which has already experienced decades of civil unrest and health system incapacity. Depending on the pathogen, it may necessitate the presence of well-trained health workers, facilities, protective equipment, and laboratories with diagnostic, therapeutic, and preventive capabilities. Although surveillance is a preventive measure, primary healthcare structures in low income, high-risk countries like the CAR are on the front lines of disease emergence, providing crucial support for surveillance systems. The CAR public health system is therefore a critical player in both epidemiological surveillance and the provision of care in future epidemics. Strengthening health systems at all levels will be crucial to avoiding a catastrophic epidemic.

\section{Conclusions}

Our historical analysis of epidemiological surveillance in the CAR reveals certain continuities and changes over the past century: the territory is a long-standing "hotspot" of disease emergence, but a "blind spot" for iterations of colonial, international, and global health. Substantial investment and collaboration with external (colonial, then international) institutions and researchers are one continuity characterizing CAR's surveillance system from its beginnings. Despite substantial changes in surveillance methods over the past century, our investigation indicates that surveillance and control efforts are not politically neutral and have catalyzed political tensions, from sleeping sickness to AIDS.

If surveillance capacity is of critical global importance, so too are genuine international, philanthropic, and bilateral contributions to improve CAR's health system. Certainly continued attention to strengthening surveillance and 
response to epidemic outbreaks is critical, but attention to primary care is long overdue. As both a hotspot and a blind spot for global health, the CAR signals the need to reorient health interventions to address the long-term health of Central African people.

Acknowledgements PMD wants to thank Guillaume Lachenal for his support. We want to thank Dominique Dupenne and Daniel Demellier for their help at the Department of Archives at the Pasteur Institute in Paris. We are also very grateful to Jean-Pierre Lombart for his welcome at the Institut Pasteur de Bangui. This work was supported by Fonds de Recherche Québécois Société et Culture-FRQSC (2016B3-189967), the Agence Nationale de la Recherche sur le SIDA et les Hépatites (12288), and the Agence Nationale de la Recherche (ANR 31-CE31-004-001).

\section{Compliance with ethical standards}

Conflict of interest The authors declare no conflict of interest.

Informed consent Informed consent was obtained from all individual participants included in the study.

Ethical approval This research was approved by the following ethics committees: Comité d'Evaluation Ethique INSERM (IRB000003888), Approval Number 15-273 and the Comité d'Ethique de la Recherche en Santé (Université de Montréal), Certificate Number 18-045 CRERED-D.

Human and animal rights All procedures performed in studies involving human participants were in accordance with ethical standards of relevant institutional and national research committees, as well as with the 1964 Helsinki declaration and its later amendments or comparable ethical standards. All informants provided written informed consent prior to participating in the study.

\section{References}

Anonymous1 (2015) Interview with former Institut Pasteur of Bangui researcher, November 22, 2015

Anonymous2 (2015) Interview with former Institut Pasteur of Bangui researcher, December 5, 2015, Lyon

Bado JP (2011) Eugène Jamot, 1879-1937: le médecin de la maladie du sommeil ou trypanosomiase. Karthala Editions, Paris

Bell D (2003) World Health Organization Working Group on International and Community Transmission of SARS. Public health interventions and SARS spread. Emerg Inf Dis 10(11):1900-1906

Bonwitt J, Dawson M, Kandeh M, Ansumana R, Sahr F, Brown H, Kelly AH (2018) Unintended consequences of the "bushmeat ban' in West Africa during the 2013-2016 Ebola virus disease epidemic. Soc Sci Med 200:166-173

Brown H, Kelly A (2014) Material proximities and hotspots: toward an anthropology of viral hemorrhagic fevers. Med Anthropol Q 28:280-303. https://doi.org/10.1111/maq.12092

Cabinet du Gouverneur Oubangui-Chari (1917) Avant-projet d'organisation d'un secteur temporaire medical dans l'Oubangui Chari. Archives diplomatiques de Nantes, fonds gouverneur Bangui: 1907-1960, 67PO/1, article 77, cotes 442

Coldiron ME, Touré O, Frank T, Bouygues N, Grais RF (2018) Outbreak of pneumococcal Meningitis, Paoua Subprefecture,
Central African Republic, 2016-2017. Emerg Infect Dis 24(9): 1720

Conan (1913) Organisation du Service de Santé en Afrique Equatoriale Française. Ann d'Hyg Colon 16:1-73

Craddock SL, Giles-Vernick T, Gunn J (2010) Mobility restrictions, isolation, and quarantine: historical perspectives on contemporary debates: Learning from Past Pandemics. In Influenza and Public Health: Learning from Past Pandemics. Earthscan Press, London

Deitte (1918a) Affaires courantes, à Lieutenant Gouverneur, Crampel. No. 660, 29 novembre 1918. Archives diplomatiques de Nantes, Fonds Ambassade, fonds gouverneur Bangui: 1907-1960, 67PO/ 1 , article 77 , cotes 444

Deitte (1918b) Affaires courantes, à Sibut, Bouca, Bambari, Crampel. No. 665, 2 décembre 1918. Archives diplomatiques de Nantes, fonds gouverneur Bangui: 1907-1960, 67PO/1, article 77, cotes 444

Deitte (1918c) Affaires courantes, à Lieutenant Gouverneur, Crampel. No. 670, 3 décembre 1918. Archives diplomatiques de Nantes, fonds gouverneur Bangui: 1907-1960, 67PO/1, article 77, cotes 444

Deitte (1918d) Affaires courantes, à circonscription Kemo. No. 716, 11 décembre 1918 Archives diplomatiques de Nantes, fonds gouverneur Bangui: 1907-1960, 67PO/1, article 77, cotes 444

Dozon JP (1985) Quand les Pastoriens traquaient la maladie du sommeil. Sci Soc Santé 3(3):27-56

Fearnley L (2010) Epidemic intelligence. Langmuir and the birth of disease surveillance. Behemoth J Civ 3(3):36-56

Germain M, Sureau P, Hervé JP, Fabre J, Mouchet J, Robin Y et al (1976) Isolements du virus de la fièvre jaune à partir d'Aedes du groupe A. Africanus (Theobald) en République Centrafricaine: importance des savanes humides et semi-humides en tant que zone d'émergence du virus amaril. Cahiers ORSTOM. Sér Entomol Méd Parasitol 14(2):125-139

Giles-Vernick T, Keck F, Delarocque-Astagneau E (2011) La surveillance en santé publique: aspect historique et sociopolitique. In: Astagneau P, Ancelle T (eds) Surveillance Epidémiologique. Lavoisier, Paris

Gonzalez JP, Saluzzo JF, Hervé JP, Geoffroy B (1979) Enquête sérologique sur la prévalence des arbovirus chez l'homme en milieu forestier et périforestier de la région de la Lobaye (République centrafricaine). Bull Soc Pathol Exot Fil 72:5-6

Gonzalez JP, McCormick JB, Georges AJ, Kiley MP (1984) Mobala virus: biological and physicochemical properties of a new arenavirus isolated in the Central African Republic. Ann l'Inst Pasteur/Virol 135(2):145-158

Graboyes M (2018) The experiment must continue: medical research and ethics in East Africa, 1940-2014. Ohio University Press, Athens

Headrick R (1994) Colonialism, health and illness in French Equatorial Africa, 1885-1935. African Studies Association Press, Atlanta

Jamot E (1920) Essai de prophylaxie médicale de la maladie du sommeil dans l'Oubangui-Chari. Bull Soc Pathol Exot 13:343-376

Kalenga OI, Moeti M, Sparrow A, Nguyen V-K, Lucey D, Ghebreyesus TA (2019) The ongoing ebola epidemic in the democratic Republic of Congo, 2018-2019. N Engl J Med. https://doi.org/10.1056/nejmsr1904253

Kalthan E, Tenguere J, Ndjapou SG, Koyazengbe TA, Mbomba J, Marada RM et al (2018) Investigation of an outbreak of monkeypox in an area occupied by armed groups, Central African Republic. Méd Mal Infect 48(4):263-268

Keshavjee S (2014) Blind spot: how neoliberalism infiltrated global health, vol 30. Univ of California Press, California 
Lakoff A (2010) Two regimes of global health. Hum Int J Hum Rights Humanit Dev 1(1):59-79

Lamblin (1918) Lettre au Gouverneur Général de l'AEF, 22 mars 1918. Archives diplomatiques de Nantes, fonds gouverneur Bangui: 1907-1960, 67PO/1, article 77, cotes 442

Lamblin (1919) Lettre au Dr. Beurrier, 16 octobre 1919. Archives diplomatiques de Nantes, fonds gouverneur Bangui: 1907-1960, $67 \mathrm{PO} / 1$, article 77 , cotes 442

Lesbordes JL, McCormick JB, Beuzit Y, Ramiara JP, Vohito D, Meunier DMY et al (1985) Aspects cliniques du SIDA en République Centrafricaine. Méd Trop 45(4):405-411

Lyons M (2002) The colonial disease: a social history of sleeping sickness in northern Zaire, 1900-1940. Cambridge University Press, Cambridge

Mann J (1986) Worldwide strategies for HIV control: WHO's special programme on AIDS. Law Med Health Care 14(5-6):290-297

Meunier DM, Johnson ED, Gonzalez JP, Georges-Courbot MC, Madelon MC, Georges AJ (1987) Current serologic data on viral hemorrhagic fevers in the Central African Republic. Bull Soc Pathol Exot Fil 80(1):51-61

Moulin AM (1992) Patriarchal science: the network of the overseas Pasteur Institutes. In: Petitjean P, Jami C, Moulin AM (eds) Science and empires. Springer, Dordrecht, pp 307-322

Musambachime MC (1993) The influenza epidemic of 1918-1919 in Northern Rhodesia. Zamb J Hist 6-7:46-73

Muyembe-Tamfum JJ, Mulangu S, Masumu J, Kayembe JM, Kemp A, Paweska JT (2012) Ebola virus outbreaks in Africa: past and present. Onderstepoort J Vet Res 79(2):06-13

Packard RM (2016) A history of global health: interventions into the lives of other peoples. JHU Press, Baltimore

Pepin J (2011) The origin of AIDS. Cambridge University Press, Cambridge
Rachas A, Nakouné E, Bouscaillou J, Paireau J, Selekon B, Senekian D et al (2014) Timeliness of yellow fever surveillance, Central African Republic. Emerg Infect Dis 20(6):1004

RGHP (2003) Recensement général de la population, République Centrafricaine, année 2003. https://ireda.ceped.org/inventaire/ ressources/caf-2003-rec-o_rca_en_chiffres.pdf. Accessed 5 Dec 2019

Ricau (1918) Chef du Service de Santé de l'Oubangui-Chari au Directeur Santé, Brazzaville, 3 Décembre 1918. Archives diplomatiques de Nantes, Fonds Ambassade, fonds gouverneur Bangui: 1907-1960, 67PO/1, article 77, cotes 444

Saluzzo JF, Vincent T, Miller J, Veas F, Gonzalez JP (2017) Arbovirus discovery in central African Republic (1973-1993): Zika, Bozo, Bouboui, and More. Ann Infect Dis Epidemiol 2(3): 1022

Sonné W (1994) Eugène Jamot: son œuvre lui a survécu, il n'appartient plus qu'à l'histoire, à la science et à l'humanité. Méd d'Afr Noire 41:74-75

Steverding D (2010) The development of drugs for treatment of sleeping sickness: a historical review. Parasites Vectors 3(1): 15

Tilley H (2011) Africa as a living laboratory: empire, development, and the problem of scientific knowledge, 1870-1950. University of Chicago Press, Chicago.

UNDP (2019). http://hdr.undp.org/en/countries/profiles/CAF. Accessed 26 June 2019

Worboys M (1994) The comparative history of sleeping sickness in east and central Africa, 1900-1914. Hist Sci 32(1):89-102

Publisher's Note Springer Nature remains neutral with regard to jurisdictional claims in published maps and institutional affiliations. 